\title{
TOWARDS SUSTAINABILITY THROUGH INDUSTRY 4.0 AND SOCIETY 5.0
}

\author{
SALIMOVA Tatiana ${ }^{1}$, VUKOVIC Natalia ${ }^{2}$, GUSKOVA Nadezhda ${ }^{3}$
}

${ }^{1}$ National Research Mordovia State University (RUSSIA)
${ }^{2}$ Ural Federal University (RUSSIA)
${ }^{3}$ National Research Mordovia State University (RUSSIA)
Emails: t.a.salimova@econom.mrsu.ru, shpak17121978@gmail.com

\begin{abstract}
This section provides general information about actual development directions of the concepts of Industry 4.0 and Society 5.0 in context of sustainable development. For the analysis of relations with sustainability of these concepts we will estimate their relations with sustainable development goals (SDGs). Also, we were investigating the case study of Russia in the context of transformation to Industry 4.0 and Society 5.0. As the research results, we conclude, that further success of the digital and socio-economic transformation will directly depend on the effectiveness and consistency of the joint efforts of government structures, the business community, and social institutions, in addressing the challenges of sustainable development of the national economy.
\end{abstract}

Keywords: Industry 4.0, Society 5.0, fourth industrial revolution, sustainable development, sustainability, SDGs

JEL: M10, O33

UDC: 005.332:330.341.1(100) "20"

330.342.24

COBISS.SR-ID 28646409

\section{Introduction}

Scientific and technological progress has led to environmental conditions aggravation and socio-economic tensions throughout the world. Unfavorable environmental conditions complicate the task of sustainable development [1]. The achievement of key tasks of social and economic programs in most countries is increasing the welfare of the population, but does not provide the necessary quality of life. This determines the essence and direction of modern society's modernization as a process of ensuring technological progress in the field of economic development, and maintaining a safety environment constitutes the essential content of the fourth industrial revolution.

On the other hand, the fourth industrial revolution and the Industry 4.0 concept, initiate the global challenge for sustainable development [2]. From one side, industrial digitalization can make a positive contribution to the problem of emissions and resource use, and when it is necessary to use virtual reality for business projects [3, 4]. Industrial digitalization could be the reason for unemployment and new social challenges [5]. This imbalance is settled by the approach of the concept Society 5.0, or smart society concept $[6,7,8]$.

Also, it is evident that it is not possible to prevent a fourth industrial revolution and industrial digitalization, which initiates some challenges for sustainable development. But this 
situation was the driver for the development of a new, more sustainable concept of digitalization, Society 5.0, which is developing beyond Industry 4.0 and is oriented on sustainable development.

\section{Theoretical Basis of Industry 4.0 and Society 5.0 in the context of Sustainable Development}

This section provides general information about actual development directions of the concepts of Industry 4.0 and Society 5.0. This section is structured as follows. First, we present the concept of Industry 4.0, the main elements of the concept of Society 5.0, and their relationship. Next, we will analyze their relations with SDGs and sustainable development.

The idea of the Fourth Industrial Revolution and smart factories was first presented by the President of the world economic forum, Karl Schwab, in Davos (2017) [9]. From this moment, many scientists around the world started to research more actively and develop the idea of Industry 4.0 and smart factories, and also in national strategies or programs of economic digitalization.

The smart factory idea, new approaches to exploit the possibilities offered by new technological developments in the context of Industry 4.0., were investigated by many scientists, especially in the national context, in Austria by Coumans [10], in Italy by Dassisti, Siragusa and Semeraro [11], in Sweden by Vestin, A., Säfsten, K., Löfving, M. [12] etc. In Russia, a country with a wide range of developed industries, the topic was investigated by Medovnikov, Oganesyan, Styrin, Abdrakhmanova, Rozmirovich, Merkulova, Bikbulatova (2017) [13], Vasin, Gamidullaeva, Shkarupeta, Finogeev, Palatkin [14], Popkova, Sergi [15] (2018).

The common conclusion in many of these researches is that the terms of Industry 4.0, fourth industrial revolution, and digital transformation, are considered synonymous. The foundation of smart factory and Industry 4.0 concepts is based on the massive introduction of cyber-physical systems into production, and an increase in the volume of interaction between machines in the production process by endowing them with artificial intelligence. In production, smart factories use a wide range of technologies, from 3D printing to drones, robotics, etc. [16, 17].

Also, industry 4.0 is developing a variety of business models: companies looking for customer - oriented solutions on the Internet, organizations that provide indirect services using platform workers, crowdsourcing, non-standard employment, etc. [18, 19]. These changes allow an increase in production, improve product quality, and reduce production costs in. All these factors improve business competitiveness enormously.

However, the robotization of industrial production automatically leads to negative social consequences, namely the reduction of jobs. The solution to this problem is not encompassed by the concept of smart factories. At the same time, solving the problem for digital enterprises retraining and employing the released personnel is a necessary process to ensure the socioecological and economic sustainability of the modern world. The concepts of Industry 5.0, which was promoted by Michael Rada in 2015[20], and Society 5.0 [21], were developed beyond the Industry 4.0 concept, as the scientific answer to the socio-economic challenges of Industry $4.0[22,23]$.

The main idea of the concepts of Industry 5.0 and Society 5.0 is developing from digital manufacturing to digital society $[24,25,26,27,28]$. Social orientation and technical innovations from Industry 4.0 developed the concept of Industry 5.0 as a universal model of sustainable development. The main idea of the concepts of Industry 5.0 and Society 5.0 is the following: digital technologies for the development of society. 
The leading scientists in Industry 4.0 and Industry 5.0, K. Schwab and N. Davies, conclude in their publication: "To take advantage of the fourth industrial revolution, we should not consider promising technologies as simple tools that are completely under our conscious control, or as external forces that cannot be controlled.

Instead, we should try to understand how and where human values are embedded in new technologies, and how technologies can be applied for the common good, environmental protection, and human rights" [9]. The same conclusion is made by scientists for the concept of Society 5.0: according to Ozgür Onday [24], although Society 5.0 is a Japanese development system, it is not limited to Japan, since its goals are equivalent to Sustainable Development Goals [24].

On the other hand, there are also alternative points of view on the idea of Society 5.0, considering the socio-economic and cross-cultural problems of spreading the ideas of Society 5.0 [29, 30, 31]. Professor Bruno Salgues [28] notes the danger of underestimating, misunderstanding the consequences of upcoming social changes, and their unpredictability in the Society 5.0 concept [28].

So, sustainability is a challenge for the concept of Industry 4.0 and also for the concepts of Industry 5.0 and Society 5.0 [32, 33]. It is because the concept of Society 5.0 was designed after the concept Industry 4.0. [32].

In Table 1 we investigate the relations of Industry 4.0 and Society 5.0 concepts with sustainable development. We combine the research of Silvia H. Bonilla, Helton R. O. Silva, Marcia Terra da Silva, Rodrigo Franco Gonçalves 1,2 and José B. Sacomano (Graduate Program in Production Engineering, University of São Paulo, Brazil). They conducted a literature-based analysis to discuss the sustainability impact and challenges of Industry 4.0 from four different scenarios: deployment, operation and technologies, integration and compliance with the sustainable development goals, and long-term scenarios [35].

Also, we used the results of the research of Mayumi Fukuyama, general manager and chief information officer of the Technology Management Center, Technology Strategy Office, Research \&Development Group, Hitachi, (Japan). This research is prepared by Mayumi Fukuyama and based on material from the Japan Business Federation (Keidanren) "Society 5.0 for SDGs" [6]. Due to results of analyses (Table 1) the concept of Society 5.0, which is called as smart society, has strong relations with DSGs. In Table 1 it is presented that the concept of Industry 4.0 has relations and positive influence on 4 of 17 SDGs or 23,5\% of SDGs. It confirms the fact that the concept of Industry 4.0 has not strong correlation with sustainable development and many scientists think the same [33].

Due to the Table 1, it is important to notice that the concept of Society 5.0 has relations and positively influence on all 17 SDGs [36] and could be the model of sustainable development.

Table 1. Industry 4.0 and Society 5.0 influence on Sustainable Development Goals

\begin{tabular}{|c|c|c|c|}
\hline № & SDG topics [34] & $\begin{array}{l}\text { Positive influence } \\
\text { of Industry } 4.0 \text { [35] }\end{array}$ & $\begin{array}{l}\text { Positive influence } \\
\text { of Society } 5.0[6]\end{array}$ \\
\hline 1 & End poverty in all its forms everywhere & & + \\
\hline 2 & $\begin{array}{l}\text { End hunger, achieve food security and improved } \\
\text { nutrition and promote sustainable agriculture }\end{array}$ & & + \\
\hline 3 & $\begin{array}{l}\text { Ensure healthy lives and promote well-being for all at all } \\
\text { ages }\end{array}$ & & + \\
\hline 4 & $\begin{array}{l}\text { Ensure inclusive and equitable quality education and } \\
\text { promote lifelong learning opportunities for all }\end{array}$ & & + \\
\hline 5 & $\begin{array}{l}\text { Achieve gender equality and empower all women and } \\
\text { girls }\end{array}$ & & + \\
\hline 6 & $\begin{array}{l}\text { Ensure availability and sustainable management of water } \\
\text { and sanitation for all }\end{array}$ & & + \\
\hline
\end{tabular}




\begin{tabular}{|c|c|c|c|}
\hline 7 & $\begin{array}{l}\text { Ensure access to affordable, reliable, sustainable and } \\
\text { modern energy for all }\end{array}$ & + & + \\
\hline 8 & $\begin{array}{l}\text { Promote sustained, inclusive and sustainable economic } \\
\text { growth, full and productive employment and decent } \\
\text { work for all }\end{array}$ & & + \\
\hline 9 & Increase Industry, Innovation, and Infrastructure & + & + \\
\hline 10 & $\begin{array}{l}\text { Build resilient infrastructure, promote inclusive and } \\
\text { sustainable industrialization and foster innovation }\end{array}$ & & + \\
\hline 11 & $\begin{array}{l}\text { Make cities and human settlements inclusive, safe, } \\
\text { resilient and sustainable }\end{array}$ & & + \\
\hline 12 & Ensure sustainable consumption and production patterns & + & + \\
\hline 13 & $\begin{array}{l}\text { Take urgent action to combat climate change and its } \\
\text { impacts }\end{array}$ & + & + \\
\hline 14 & $\begin{array}{l}\text { Conserve and sustainably use the oceans, seas and } \\
\text { marine resources for sustainable development }\end{array}$ & & + \\
\hline 15 & $\begin{array}{l}\text { Protect, restore and promote sustainable use of terrestrial } \\
\text { ecosystems, sustainably manage forests, combat } \\
\text { desertification, and halt and reverse land degradation and } \\
\text { halt biodiversity loss }\end{array}$ & & + \\
\hline 16 & $\begin{array}{l}\text { Promote peaceful and inclusive societies for sustainable } \\
\text { development, provide access to justice for all and build } \\
\text { effective, accountable and inclusive institutions at all } \\
\text { levels }\end{array}$ & & + \\
\hline 17 & $\begin{array}{l}\text { Strengthen the means of implementation and revitalize } \\
\text { the global partnership for sustainable development }\end{array}$ & & + \\
\hline
\end{tabular}

So, the results of Table 1 confirm the hypotheses of some researches about it [25]. Also, the concept of Society 5.0 is closely correlated with the followings SDGs as Zero Hunger (SDG 2), Clean Water and Sanitation (SDG 6), Sustainable Cities and Communities (SDG 11), Life Below Water (SDG 14), Life on Land (SDG 15) [52], which by the research of Áron Szennay, Cecília Szigeti, Norbert Kovács and Dániel Róbert Szabó strongly linked to ecological services.

\section{Industry 4.0 and Society 5.0 in Russia}

In the global competition Index of the World Economic Forum (WEF) [37] Russia has 43 places in 2017 due to the high quality of education, infrastructure development and innovation potential. So, it means that that Russia has potential for the development of the concept Industry 4.0. Industry 4.0 and Society 5.0 concepts are in the top of research interests of Russian scientists. Russian science citation Index (RSCI) academic service in 2020 presented more than 6 thousand publications (articles, books, conference proceedings, theses) with term "digitalization" in the title / Also RSCI indexed more than 50 thousand publications with the term "digital", about 13 thousand publications with the term "smart" and about 600 publications with the term "the fourth industrial revolution-industry 4.0".

Among the major and most well-known works of Russian researchers in the field of the fourth industrial revolution and digitalization of the economy are, in particular, publications Medovnikov D., Oganesyan T., Styrin E., Abdrakhmanova G., Rozmirovich S., Merkulova D., Bikbulatova Yu. [13], Glazyev S. [38] and others.

The key issue of most Russian research on the subject under analysis is the challenges and opportunities that are relevant for domestic business in various sectors, as well as for public administration, education, and other areas of the economy and society in connection with the expansion and increasing pace of digitalization. Leading Russian universities and business schools, such as the Higher School of Economics, business-school Skolkovo and others, are engaged in studying the process of digitalization of the economy in Russia. 
Due to one of the best researches of leading national universities Russia, HSE, Russia is still on the way to Industry 4.0 and Society 5.0. Due to this research almost $60 \%$ of the urban population in Russia is well provided with digital services and more than $50 \%$ of citizens have local digital services in cities of the Russian Federation (Results of report "Digitalization in small and medium cities of Russia" of Graduate School of Urbanism HSE, 2018) [39]. For cities situation is totally opposite and should be developed. Especially because of agglomeration reason [40], because digitalization of big cities influences positively on the speed of digitalization of small cities in surrounded [41, 42].

Also, this research group form Russian university HSE compare digital skills of Russia with world, Western Europe and Eastern Europe [39]. The results of HSE research proved that that there are no strong imbalances between federal districts of Russia and it means that the situation with Affordability of local digital services in Russian cities equable for all country [43]. The leading federal district is Ural federal district, the leading city is the capital of the country, Moscow [43].

According to researches of other Russian scientists [44, 45, 46, 47, 48, 49, 50] and to results of HSE research [39, 43] development of the digital economy in Russia as a key factor in economic growth and improving the quality of life of the population, awareness of the need for digital transformation at both the company and state levels will definitely come. But this will happen when most of the new digital markets have already been formed, and new technologies have been developed and patented by foreign companies. Also, the field of citizens and cities digitalization is investigated good, but there are no detailed official statistics or research about Russian business transformation in digitalization. We propose that it will be very difficult for Russian businesses to integrate into the digital ecosystem because of economic and social reasons.

\section{Conclusion}

Industry 4.0 start to implement in all world and it is not possible to stop this process. In the most progressing cases the concept of Industry 4.0 id transforming to Society 5.0, which is the model of sustainable development.

On the case study of Russia, it can be concluded that the economy of the Russia and Russian business community are still on the way to a digital society, Industry 4.0 and Society 5.0.I. The further success of the digital and socio-economic transformation of worlds economy it will directly depend on the effectiveness and consistency of joint efforts of government structures, the business community and social institutions in addressing the challenges of sustainable development of the national economy.

\section{Acknowledgments}

The reported study was funded by RFBR, project number 20-010-00550 «Ensuring of sustainable competitiveness of innovative cluster formations in industry in the context of Society 5.0 challenges».

\section{REFERENCES}

[1] Eydenzon, D., Ganieva, I., Shpak, N. Socio-economic and environmental aspects of the industry imbalances in the regional economy. Economy of Region. 2013, 4, 36. pp. 115-122.

[2] Kiel, D., et al., Sustainable industrial value creation: Benefits and challenges of industry 4.0. International Journal of Innovation Management, 2017, 21. Jg., Nr. 08, S. 1740015.

[3] Sniderman, Brenna; Mahto, Monika; Cotteleer, Mark J. Industry 4.0 and manufacturing ecosystems: Exploring the world of connected enterprises. Deloitte Consulting, 2016. 
[4] Grunler, A., et al., A low energy demand scenario for meeting the $1.5 \mathrm{C}$ target and sustainable development goals without negative emission technologies. Nature energy, 2018, 3. Jg., Nr. 6, S. pp. 515-527.

[5] Zemtsov, S. New technologies, potential unemployment and 'nescience economy'during and after the 2020 economic crisis. Regional Science Policy \& Practice, 2020.

[6] Fukuyama, M. Society 5.0: Aiming for a new human-centered society. Japan Spotlight, 2018, 1. Jg., pp. 47-50.

[7] Onday, O. (2019). Japan's society 5.0: Going beyond Industry 4.0. Bus Eco J, 10(389), 2.

[8] Takahashi, T. (2018). Behavioral Economics of Addiction in the Age of a Super Smart Society: Society 5.0. Oukan (Journal of Transdisciplinary Federation of Science and Technology), 12(2), pp. 119-122.

[9] Schwab K. The fourth industrial revolution. Currency; 2017 Jan 3.

[10] Coumans F. Smart Factories Need Space and Time Anchors. GIM International - the worldwide magazine for geoinformatics. 2018, 32,1, pp. 21-30.

[11] Dassisti M, Siragusa N, Semeraro C. Exergetic model as a guideline for implementing the smart-factory paradigm in small medium enterprises: the brovedani case. Procedia CIRP. 2018 Jan 1, 67, pp. 534-9.

[12] Vestin, A., Säfsten, K., Löfving, M. (2018). On the way to a smart factory for single-family wooden house builders in Sweden. Procedia Manufacturing, 25, pp. 459-470.

[13] Medovnikov, D., Oganesyan, T., Styrin, E., Abdrakhmanova, G., Rozmirovich, S., Merkulova, D., Bikbulatova, Yu. (2017) Digital economy: global trends and practice of Russian business: report. Moscow. HSE, p. 121.

[14] Vasin, S., Gamidullaeva, L., Shkarupeta, E., Finogeev, A., Palatkin, I. (2018). Emerging trends and opportunities for industry 4.0 development in Russia.

[15] Popkova, E. G., Sergi, B. S. (2018). Will industry 4.0 and other innovations impact Russia's development. Exploring the future of Russia's economy and markets: Towards sustainable economic development, pp. 51-68.

[16] The new High-Tech Strategy Innovations for Germany. Berlin: Bundesministerium für Bildung und Forschung/Federal Ministry of Education and Research (BMBF) Division Innovation Policy Issues, 2014. P. 58.

[17] Kagermann, Henning, et al., Recommendations for implementing the strategic initiative Industrie 4.0: Securing the future of German manufacturing industry; final report of the Industrie 4.0 Working Group. Forschungsunion, 2013.

[18] Müller, J. M., Buliga, O., Voigt, K. I. (2018). Fortune favors the prepared: How SMEs approach business model innovations in Industry 4.0. Technological Forecasting and Social Change, 132, pp. 217.

[19] Saniuk, S., Grabowska, S., Gajdzik, B. (2020). Social Expectations and Market Changes in the Context of Developing the Industry 4.0 Concept. Sustainability, 12(4), p. 1362.

[20] Rada, M. (2017). Industry 5.0 Definition.

[21] Feigenbaum, E., \& Shrobe, H. (1993). The Japanese national Fifth Generation project: introduction, survey, and evaluation. Future Generation Computer Systems, 9(2), pp. 105-117.

[22] Liao, Y., Deschamps, F., Loures, E. D. F. R., Ramos, L. F. P. (2017). Past, present and future of Industry 4.0-a systematic literature review and research agenda proposal. International journal of production research, 55(12), pp. 3609-3629.

[23] Skobelev, P. O., Borovik, S. Y. (2017). On the way from Industry 4.0 to Industry 5.0: From digital manufacturing to digital society. Industry 4.0, 2(6), pp. 307-311.

[24] Önday, Ö. (2020). Society 5.0-Its Historical Logic and Its Structural Development. Journal of Scientific Reports, 2(1), pp. 32-42.

[25] Salgues, B. (2018). Society 5.0: Industry of the Future, Technologies, Methods and Tools. John Wiley \& Sons.

[26] Potočan, V., Mulej, M., Nedelko, Z. (2020). Society 5.0: balancing of Industry 4.0, economic advancement and social problems. Kybernetes.

[27] Permatasari, Deviana; Iqbal, Mochamad. Strenthing entrepreneurship with a grit system and transformational technology to face Society 5.0 in Asian community. International Conference of One Asia Community. 2019. S. pp. 104-109.

[28] Salgues, B. (2018). Society 5.0: industry of the future, technologies, methods and tools. John Wiley \& Sons.

[29] Shchelkunov, M. D., Karimov, A. R. (2019). Society 5.0 in technological, social and anthropological dimensions. Bulletin of Economics, law and sociology, 3.

[30] Fathi, M., Khakifirooz, M., Pardalos, P. M. (Eds.). (2019). Optimization in Large Scale Problems: Industry 4.0 and Society 5.0 Applications (Vol. 152). Springer Nature. 
[31] Tselishchev, I. S. (2015). The Japanese economy is not going through the best of times. Economic strategies, (8), p. 41.

[32] Onday, O. (2019). Japan's society 5.0: Going beyond Industry 4.0. Bus Eco J, 10(389), 2.

[33] García-Muiña, F. E., Medina-Salgado, M. S., Ferrari, A. M., Cucchi, M. (2020). Sustainability Transition in Industry 4.0 and Smart Manufacturing with the Triple-Layered Business Model Canvas. Sustainability, 12(6), p. 2364

[34] Sustainable development. UNIDO.

[35] URL: http://sustainabledevelopment.un.org/focussdgs.html

[36] Bonilla, Silvia H., et al., Industry 4.0 and sustainability implications: A scenario-based analysis of the impacts and challenges. Sustainability, 2018, 10. Jg., Nr. 10, S. 3740.

[37] Nino, F. S. (2015). Sustainable Development Goals - United Nations. United Nations Sustainable Development.

[38] Gap, G. G. (2017). World economic forum. Cologny/Geneva.

[39] Glazyev, S. (2017). The Great Digital Economy: Challenges and Prospects for the Economy of the 21st Century. Zavtra [Tomorrow], (37), 1241.

[40] Digitalization in small and medium cities of Russia. Graduate School of Urbanism HSE in 2018. URL:https://www.hse.ru/data/2018/06/06/1149766040/2018-06-GSU-HSE_pres_v6.pdf

[41] Vukovic, D. B., Larionova, V. A., Platonov, A. M., Vukovic, N. A. (2017). Does agglomeration process exist in small provincial urban centers? Evidences from Sverdlovsk region. Journal of The Geographical Institute Jovan Cvijic Sasa, 67(3), pp. 297-315.

[42] Vukovic, Natalia; Rzhavtsev, Andrey; Shmyrev, Victor. Smart city: The case study of Saint-Peterburg 2019. International Review, 2019, Nr. 1-2, S. pp. 15-20.

[43] Mingaleva, Z., Vukovic, N., Volkova, I., Salimova, T. (2020). Waste management in green and smart cities: A case study of Russia. Sustainability, 12(1), 94.

[44] The results of measuring the index "Digital Russia" constituent entities of the Russian Federation in 2018 by Center for Financial Innovation and Cashless Economy of the Moscow School of Management SKOLKOVO.

URL: https://finance.skolkovo.ru/downloads/documents/FinChair/Research_Reports/SKOLKOVO_Digital_R ussia_Report_Full_2019-04_ru.pdf

[45] Vasin, S., Gamidullaeva, L., Shkarupeta, E., Finogeev, A., Palatkin, I. (2018). Emerging trends and opportunities for industry 4.0 development in Russia.

[46] Popkova, E. G., Sergi, B. S. (2018). Will industry 4.0 and other innovations impact Russia's development. Exploring the future of Russia's economy and markets: Towards sustainable economic development, pp. 51-68.

[47] Martynov, V. V., Shavaleeva, D. N., Zaytseva, A. A. (2019, September). Information Technology as the Basis for Transformation into a Digital Society and Industry 5.0. In 2019 International Conference Quality Management, Transport and Information Security, Information Technologies (IT\&QM\&IS) (pp. 539-543). IEEE.

[48] Salimova, T. A., Biryukova, L., Shilkina, A., Khakhaleva, E. (2018). Towards a methodology of sustainable competitiveness of organization. International Journal of Civil Engineering and Technology, 9(11), pp. 161-172.

[49] Andreeva, G. N., Badalyants, S. V., Bogatyreva, T. G., Borodai, V. A., Dudkina, O. V., Zubarev, A. E., Sher, M. L. (2018). Development of the digital economy in Russia as a key factor of economic growth and improving the quality of life of the population.

[50] Salimova, T., Guskova, N., Krakovskaya, I., Sirota, E. (2019, March). From industry 4.0 to Society 5.0: challenges for sustainable competitiveness of Russian industry. In IOP Conference Series: Materials Science and Engineering (Vol. 497, No. 1, p. 012090). IOP Publishing.

[51] Stroiteleva, T. G., Kalinicheva, E. Y., Vukovich, G. G., Osipov, V. S. (2019). Peculiarities and problems of formation of Industry 4.0 in modern Russia. In Industry 4.0: Industrial Revolution of the 21st Century (pp. 145-153). Springer, Cham.

\section{Article history:}

Received 18 October 2020

Accepted 29 November 2020 